\title{
TEACHING ENGLISH TO YOUNG LEARNERS THROUGH SONGS
}

\author{
Ani Setyaningsih
}

State University of Yogyakarta

\begin{abstract}
Globalisation brings a great impact on the use of English in any domains like business, education, IT and the like. English has become lingua franca one chooses to comunicate with others having a different language. English has spread worlwide and this phenomenon has resulted in English teching learning in primary level in many nonEnglish-speaking countries. This brings a consequence to a crucial need in teachers' education. Teachers at the primary level need to develop both competence in English use and teaching skills to young learners regarding their special characteristics. Theories in children development is needed by teachers to meet the speacial needs of children. One method suggested to meet those needs through songs. Songs help children to internalize some words and sentences in the new language. Songs also provide a link with their everyday lives and be fun. Songs can be used at any level of ages at any stage in a lesson. In the beginning of a lesson songs can be used to mark the change from one topic to another. Songs can be a break from another, more concetrate activity in the middle of a lesson and used to round a lesson of the end.
\end{abstract}

Keywords: teaching, young learners, songs 


\section{INTRODUCTION}

The world seems to be shrinking very rapidly as international barriers break down and people are able to get contact with other culture and languages easily. This so-called globalization of the world produces one effect that is the growing trend to use English as a world language. Nowadays, English is not a language for the English-speaking countries anymore. English has spread worldwide to the countries in the five continents. Even in some non-English-speaking countries, english is not thought as a foreign language anymore but as a second language, e.g. in Singapore, Malaysia, India, e.t.c. Today is the era after.Modern English in which English has new status as a global lingua franca and it brings consequences that English is surrounded by new cultural, linguistics, political, and economic issues. The awareness of English importance in the globalization era has made people learn this universal language consciously and it brings issues to English language learning especially in non-English-speaking countries. Students start to learn English younger. It is not taught in secondary school anymore but started to be taught at primary school, even pre-school. Thus, it urges the need to study the English language learning. It happens likewise in Indonesia.

This paper attempts to answer some questions related to the problems arisen by the teaching English at primary school, such as What Theories are Relevant to Children's Language Learning? Is Teaching English to Children Different from Adults?, Why songs?, When and How to Use Songs?, and What Can Be Taught through Songs?.

\section{DISCUSSION}

\section{A. What Theories are Relevant to Children's Language Learning?}

When we are talking about how to teach English to young learners, we cannot separate it from talking about child development in psychology point of view. This article tries to rise the work of some experts in developmental psychology. Let's have a look two of them.

1. Piaget: the child as an active learner

Piaget's concern was with how young children function in world that surrounds them and how this influences their mental development (Cameron: 2001). The child is seen as continually interacting with the world around him or her, solving problem presented by the environment. It is through actions in solving problem that learning occurs. The development of children passes through action or experience in different stage of age. Piaget assumed that children gained knowledge from experiences. Children try to make sense of the world through what they did, hear, saw, tasted, smelled, and they try to work the things out for themselves. 
Piaget introduces two concepts in which development can take a result of activity. They are assimilation and accomodation. Assimilation occurs when an action takes place without any change to the child. Meanwhile accomodation involves the child adjusting to features of the environment in some way. For child new information can be either assimilated or accomodated. In assimilation new information is adapted to support old knowledge alreay established in child's mind. In accomodation, the child modifies or changes the present understanding to fit the new information. If we apply this theory to children's language learning, then it is true the children learn from doing. We need to give them thinking time to be ready to face problems to solve. Children acquire concrete things faster then abstract ones, since they allow them to use their senses.

2. Vygotsky: the child as social

Vygotsky had a different point of view in seeing children. Whereas Piaget focused on child as an active learner alone in a world of objects, Vygotsky placed the child as an active lerner in a world of other people (Cameron: 2001). Although Vygotsky emphasized the importance of social interaction, he still paid attention to individual cognitive development. He gave an idea that a child had a potential to reach his/ her present level within a certain zone, Zone of Proximal Development (Paul: 2003). To reach this zone we cannot leave the child alone, there must be an interaction with others either other children or adults with more knowledge. Learning to do things and to think are both helped by a social interaction.

In language learning especially in non-English-speaking countries, the social interactions meet here is with teachers as children's model in acquiring a new language. Teachers need to get in touch with them using English and help them to express and extend their ability in English. Vygotsky also saw learning in terms of conflict-generating problem solving.

Theories of those of two experts have a great have a great influence in language learning. Understanding both theories help us a lot in dealing with children related to language learning.

\section{B. Is Teaching English to Children Different from Adults?}

There is a belief that we can give the same treatment to young learners, say children, and adults in teaching a language. Some teachers do not differentiate the teaching learning process of English to deifferent ages. This belief is objected by those who know children's psychology well. Obviously children have different characteristics compared to adults. 
1. Children have shortattention span.

Children get bored easily especially when children have to deal with the material that to them is boring, useless; and too difficult. Since lessons can at times be difficult for children, it is teacher's job to make it interesting, lively; and fun. Learning activities can be designed to get their interest and the material must be something familiar around them. A variety of activities can maintain children's interest and attention. Once students have interest in learning the language they will find it easier to understand and acquire it.

2. Children have a lot of natural curiosity.

Children are eager to know everything. It is their nature to be curious to explore the environment in greater detail. Don't let them down by not providing them with answers needed. Obviously it is an advantage in learning a new language if we can maximalize it and set up a situation to support it.

3. Children need to have all five senses simulated.

It will be easier for children to leam something if they use their five senses. Thus, activities should strive to go well beyond the visual and auditory modes that are usually sufficient for a classroom. Sensory aids help children to internalize concepts. The real rulers, the smell of flowers, the beat of songs, the taste of food are important elements in children's language leaming.

4. Children find it difficult to deal with abstract things and concepts.

Children are focused on what the new language can actually be used for here and now. They need to deal with authentic and meaningful language, so language taught needs to be firmly context-embedded. Generally, they have a holistic approach to language which means that they understand meaningful messages, but they cannot analyze it yet.

5. Children are sensitive.

Children egos are still being shaped. They do really care what others think of them and they are more concerned about themselves than others. Therefore the slightest nuances of communication can be negatively interpreted. Teachers need to build such an environment where children will feel confident and secure to overcome potential barriers in learning. It is important to establish a trusting relationship with the children and encourage them to do the same with their peers.

Since children have special characteristics; it takes a very special way or method to make children acquire English effectively, especially from the activities. There are many ways we can do with the activities given to children. The activities should be simple enough for the children to understand what is expected of them. The task should be within their abilities: it needs to be achievable but at the same time sufficiently stimulating for them to feel satisfied with their work. The activities should be largely orally based; 
children learn spoken language faster than written one and they find it easier. Written activities should be given sparingly with younger children. These activities must be simple enough such as completing a word, matching, filling the gaps etc. Most of all, activities must be attractive, interesting, full of joy, various, and stimulating to keep the children focused and involved.

\section{Why Songs?}

Second language learners can benefit from songs. Through word/ sound play, many 'chunks' of useful language can be incorporated into the individual's linguistic repertoire at almost at any age or level of proficiency. The use of prosodic elements, 'redundancy, and sometimes thoughtless repetitions can produce lowered anxiety: Songs' rhythms and sound repetitions carry children into appealing activities that go far beyond mere drill. There are other advantages offered by songs in language learning (Brewster, Ellis, and Girard: 2003).

1. Linguistic resource

a. Songs allow new language to be introduced and structures and vocabularies to be reinforced and recycled.

b. Songs present familiar language in new and exciting forms and in rich, imaginative context.

c. Songs provide for lots of natural and enjoyable repetition.

d. Songs can be used to develop all skills in an intregated way.

e. Songs help improve all aspects of pronunciation.

2. Psychological/Affective resource

a. Songs are motivating and fun and help develop positive attitude toward the target languge.

b. Songs are non-threatening and the more inhibited child will feel secure when singing and chanting as a class or in groups.

c. Songs can encourage a feeling of achievement and build children's self confidence by allowing them to learn chunks of . language which they can "show off" or teach to friends or members of the family.

3. Cognitive resource

a. Songs help to develop concentration, memory, and coordination.

b. Songs sensitize children to rhyming clues as aids to meaning.

c. Repetition enables children to predict what comes next and to consolidate language items.

d. Accompanying actions or gestures help to reinforce meaning.

e. The variety they provide changes the pace and atmosphere of a lesson and caters for different learning styles. 
4. Cultural resource

a. Songs are from authentic sources and can contribute to the cultural component of a language programme. Children can be encouraged to compare with those in their own language.

5. Social resource

a. Singing and chanting together is a shared social experience and helps to develop the class and group identity.

b. Songs can be used as the basis for a performance or show.

There are a lot of songs can be chosen, can be used with a variety of language learner's age at different stages, can act as a starting point for devising a program of work, can integrate with cross-curricular work, topics and stories, and can complement and supplement other resources. Songs allow all skills to be introduced to children, speaking is acquired when they sing whereas listening can be gained from catching the words or the sounds of the songs. Given a filling in gap activity, children will be able to demonstrate their ability in reading and writing.

\section{When and How to Use Songs?}

Songs can be used in many different ways: as warmness in the beginning of the lesson, as a transition from one activity to the next, to introduce new language, to practice language, to revise language, to change mood, to get everyone's attention, to channel high levels of energy, or to integrate with storytelling, games or topic work (Brewster, Ellis, and Girard: 2003).

There are some stages in using songs.

1. Set the context (build up the environment by explaining the purpose, background information)

2. Pre-teach any necessary vocabulary using visual aids, actions; realia, etc.

3. 'Play on cassette or sing to allow children' to listen, show understanding, familiarize themselves with the rhythm, tune, etc. Teachers should not bother too much if they are not good in singing. It is not a singing lesson; singing is a means to transfer the knowledge only.

4. Do further listening activities, like matching, coloring, filling in gaps; etc.

5. Work on pronunciation awareness since songs provide a good model.

6. Invite children to listen, repeat, and practice by joining in and learning to sing. Encourage children to use actions, mime, drama, gestures, etc. They will help the children memorizing the words and their meanings.- 
7. Give a written record of text along with activities. It is better to avoid giving the script in the first time introducing the song, since it is easier for the children to listen first than reading especially since English words have differences in. spelling and pronunciation.

8. Present or perform as a whole class, in groups, in rounds, in pairs, or individually. Here we set a goal for children so they have motivation to reach it.

Finally, children can make a book class by compiling the songs given by the teacher. It will likely increase their good study habit. Teachers should be selective in choosing the songs since there are some songs that are not suitable for learning a language. Good songs must have clear topic to deliver the material, do not have too many new words since it will make the students think it's difficult. Right after children feel difficult their interest in learning the language will fade away constantly. Repetition should be provided by the songs, so children will be able to memorize them easily: Songs that give enhances to children to act out the verbs in them will help making the atmosphere cheerful and alive, and it is good to keep the children's interest.

\section{E. What Can Be Taught through Songs?}

Songs can contribute to the child's global development in many ways. Songs can deliver the purpose of a certain topic. Let's take some examples of the topics.

1. Alphabet

English letters can be introduced by $A B C$ song.

ABCSong
$\begin{array}{llllllllllllll}\mathbf{A} & \mathbf{B} & \mathbf{C} & \mathbf{D} & \mathbf{E} & \mathbf{F} & \mathbf{G}\end{array}$
$\begin{array}{llllllllll}\mathbf{H} & \mathbf{I} & \mathbf{J} & \mathbf{K} & \mathbf{L} & \mathbf{M} & \mathbf{N} & \mathbf{O} & \mathbf{P}\end{array}$
$Q \quad R \quad S \quad T \cdot U$ and $\mathbf{V}$
$\mathbf{W} \mathbf{Y}$ and $\mathbf{Z}$

Now you've heard my ABC

Will you sing along with me?

This song helps children to memorize and learn letters in English. It is necessary to introduce children letters in English since again English letters are different from Indonesian's. After leaming the letters, children can be asked to mention words started by a letter the teacher gives. Along with this activity, children will learn to construct a single word with letters. 
2. Animals

Some songs can be used to introduce animals to children, like Old MacDonald Had F Farm and BINGO.

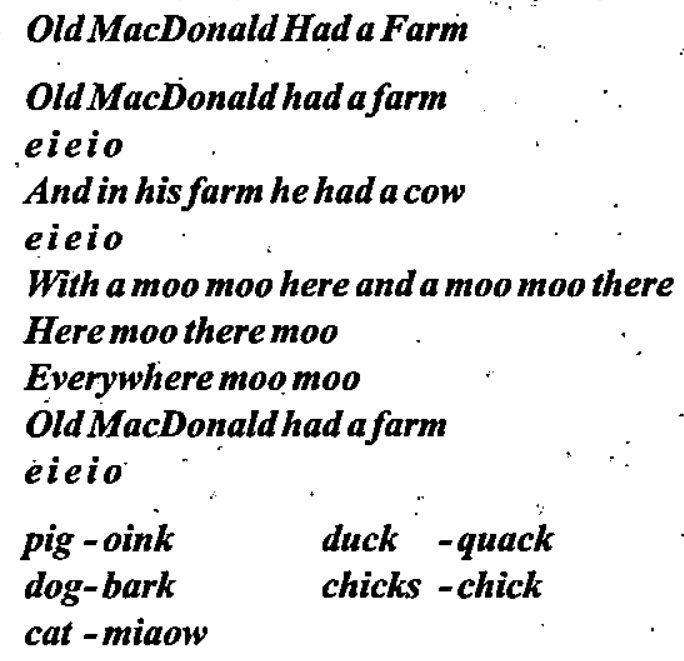

Teachers can change the name of animals into different ones; even in Old MacDonald Had a Farm teachers can introduce how the animals make a sound. If the children play a role as different animals while singing this song, it will be very great and fun.

\section{BINGO}

\section{There was a farmer had a dog \\ And BINGO was his name $O$ \\ $B I N G O$ \\ BINGO \\ BINGO \\ And BINGO was his name $O$}

In BINGO song, children learn kinds of animals and also names common for animals.

3. Parts of the Body

Head, Shoulders, Knees, and Toes and If You're Happy and You Know It are the best songs to introduce our body to children. These songs provide physical actions and exercise. Therefore, most children love them and teachers can make them more challenging by speeding up and leaving out words. 


\section{Head, Shoulders, Knees, and Toes \\ Head, shoulders, knees, and toes: \\ Knees and toes, knees and toes \\ Head, shoulders, knees and toes \\ Eyes, ears, mouth, nose}

If You're Happy and Know It

Ifyou'rehappyand you knowit

Clapyourhands

Ifyou're happy and you know it

Clapyourhands

Ifyou're happy and you knowit

And you really want to show it

Ifyou're happyandyou knowit

Clapyourhands

\section{Sad -cry yourtears \\ Angry -stampyour feet \\ Glad -shouthurray.}

In If You're Happy and You Knowi It we can also introduce feelings like happy, sad, angry, and glad, and action verbs like clapping hands, crying the tears, stamping feet, and shouting hurray.

\section{Numbers}

Numbers can be presented by Ten Little Indians song. That song reinforces, concept, of numbers and counting, and develop memory, concentration, coordination and counting.

\section{Ten Little Indians}

One little two little three little indians

Four little five little six little indians

Seven little eight little nine little indians:

Ten little indian boys 


\section{Family}

Are You Sleeping can be chosen to present this topic. Teachers can change the name of the family member while acting out the action verb provided. The action verb itself can be made various:

\section{Are You Sleeping}

Areyou sleeping, are you sleeping

Brother John, brother John

Morning bells are ringing, morning bells are ringing

Ding ding dong, ding ding dong

Sister Anne

Aunt Mary

Uncle Sam

\section{CONCLUSION}

The discussion above shows that song is one the learning resources in English teaching learning that is suitable for children regarding their characteristics. It is not, of course, the best since there is no the best method in English teaching learning. Many factors to consider influence the success of it. Teaching English through songs is one alternative for the children to acquire the foreign language easily and effectively. Songs can break down barriers among those who share the rhythm and meaning. Moreover, the repeated lyrics in songs allow the children to memorize and learn new words quickly. Since teaching is a developing art, which requires innovative and creative ideas to enrich its effectiveness, we must not hesitate to use songs in our classrooms. This resource can assist our teaching while providing a relaxed atmosphere and motivated students. Such activities are student centered, hence, by using them we give a chance to our students to express themselves, enjoy themselves during learning, and use the reserves of their minds. So there is an undeniable fact that if our concern is to provide a successful and beneficial teaching; we must consider to use songs as one way to bring the structural, pragmatic, prosodic and communicative aspects of language together, in our language classrooms. 


\section{Bibliography}

Brewster, Jean, Ellis, Gail, \& Girrard, Denis. 2003. The Primary English Teacher's Guide. Essex: Penguin English

Brown, H.D. 2001. Teaching by Priciples: An Interactive Approach to Language Pedagogy. Second Edition. San Fransisco: Addison Wesley Longman, Inc.

Cameron, Lynne. 2001. Teaching Languages to Young Learners. Cambridge: Cambridge University Press.

Citravelu, N., Sithamparam, S., \& Choon, S.T. 2002. ELT Methodology. Principles and Practice. Selangor: Penerbit Fajar Bakti Sdn.Bhd.

Diffily, Deborah \& Sassman, Charlotte.2004. Teaching Effective Classroom Routines. - New York: Scholastic Inc.

Graddol, David. 2006. English Next. Plymouth: British Council

Paul, David. 2003. Teaching English to Children in Asia. Quary Bay: Pearson Education NorthAsia Ltd.

Phillips Sarah.1997. Young Learners. Oxford: Oxford University Press

Pinter, Anamaria. 2006. Teaching Young Language Learners. Oxford: Oxford University Press.

Richard-Amato, Patricia A. 2003. Making It Happen: from Interactive to Participating Language Teaching: Theory and Practice. New York: Pearson Education

Richards, Jack C., Rodgers, Theodore S. 2001. Approaches and Method in Language Teaching. ( $2^{\text {nd }}$ ed.) Cambridge: Cambridge University Press. 